\title{
RENTAL AND MANAGEMENT POLICY OF MUNICIPAL RESIDENTIAL BUILDINGS: A CASE STUDY IN RIGA (PART TWO)
}

\author{
Iveta PUĶĪTE ${ }^{1}$, Ineta GEIPELE ${ }^{2}$, Armands PUĶĪTIS ${ }^{3}$ \\ ${ }^{1,2}$ Riga Technical University, Riga, Latvia \\ ${ }^{3}$ Rìgas Pilsētbūvnieks Ltd., Riga, Latvia \\ Corresponding author's e-mail: iveta.pukite@rtu.lv
}

\begin{abstract}
The scientific publication aims to identify risks in the maintenance of the rental housing stock. Access to housing is an essential precondition for the development and integration of the personality of each individual into society. Despite the rapid development of the state in certain sectors of the economy, the issue of inadequate accessibility and quality of housing for low-income groups of the population is becoming more and more acute. Therefore, one of the state policies is to create an adequate and rational space for all categories of Latvia's population. The aim of the article is to identify and evaluate the risks of management of rental houses owned by the municipality, their impact on efficient and high-quality maintenance and high-quality maintenance of the housing stock.
\end{abstract}

Keywords: Enterprise operation, municipal housing policy, residential rental property, risk management.

\section{INTRODUCTION}

Risk is a concept, which usually represents the possible future loss of different values. In daily management, this term is used as a synonym for the probability of losing something. Thus, the risk in its essence is a result of various scenarios that is worse than the initial situation.

The company's operational risks are described to identify the main risk areas and assess their potential impact on the enterprise operation. To make the process a real success and reduce exposure to unexpected shocks due to unsuccessful and ineffective decisions, during the company's management process it is necessary to recognise the risks, assess them, analyse the risk conditions and mitigate them. Determination of risk factors and risk effects helps determine which external factors that are outside of the company's planning and implementation boundaries and are not controlled by the company are crucial for the successful operation of the company and the achievement of sustained results (State Education development Agency Republic of Latvia, 2017).

In the real estate sector, it is essential to carry out a risk assessment by identifying risks, indexing (Ma \& Meng, 2009), identifying problems and analysing them using different methods (Carkovs \& Šadurskis, 2015). 
As a result of risk analysis, it is possible to identify the existing risk mitigation measures, develop an action plan for risk mitigation and, of course, implement this plan in the company's operations.

The research is the continuation of the research Rental and Management Policy of Municipal Residential Buildings: Housing Policy. Case Study of Riga (Part One) (Puk̦ītis, Puḳīte \& Geipele, 2017).

The object of the present research is the management of municipal residential rental property and the subject of the research is the risks of residential rental property management.

The aim of the article is to assess the management process risks of rental property in the municipality of Riga.

To achieve the aim of the article, the following tasks are put forward:

1) to research the thematic scientific literature;

2) to study and analyse the field of operation of Riga municipal enterprise;

3) to clarify enterprise operational risks, to identify the main risk areas;

4) to describe the potential impact of risks on the enterprise operation.

Limitations of the research are as follows:

1) the research covers the period of 2012-2017;

2) the management process of rental property of the municipality of Riga is investigated, and risks are assessed.

Within the framework of the research, the authors have used the following methods: descriptive and summarisation methods - to better understand the risks, the statistical and analytical methods, which involve a detailed identification of the risks.

This publication is part of the research "Rental and management policy of municipal residential buildings: A Case Study in Riga”, Part 2.

\section{THEORETICAL ASPECTS OF RISKS MANAGEMENT}

To make the process a real success and reduce exposure to unexpected shocks due to unsuccessful and ineffective decisions, during company's management process it is necessary to recognise the risks, assess them, analyse the risk conditions and mitigate them. Determination of risk factors and risk effects helps determine which external factors that are outside of the company's planning and implementation boundaries and are not controlled by the company are crucial for the successful operation of the company and the achievement of sustained results (State Education development Agency Republic of Latvia, 2017).

A risk in its essence is a result of various scenarios that lead to a worse result than planned. The term "risk" is often manifested in an economy where people invest their money and risk losing their profit. Risks can be divided into economic, health, financial, business and management, security and other. Housing management has several inherent risks - economic, social, health, and financial risks.

Risk management means a systematic approach, i.e., risk management methods should be implemented during both the preparation and implementation phases. In the implementation phase of the service, being aware of the probability of a new risk, the risk analysis and assessment should be repeatedly performed, and a plan of measures to prevent or mitigate risks should be reconsidered. 
There is a high level of uncertainty in the contemporary fast-changing global business environment that causes challenges for management decision-making process. Management of organisations employs a set of risk management practices to deal with these uncertainties and to ensure achievement of strategic objectives and fulfilling its mission. There are the Enterprise Risk Management (ERM) frameworks that provide a comprehensive and systematic approach to proactive and holistic risk management (Meiers-Meiris, Mazais, \& Lapin,a, 2017).

Risks are grouped according to the types of risks, so that the project applicant can delegate to the persons involved in the project the relevant risk mitigation or prevention tasks during the implementation of the project.

1. Management risks (Ghoshal, 1987) - the risks that affect the management and administration of the company, as well as changes in planned service schedules (Ma \& Meng, 2009), which may lead to other risks, for example, lack of managerial experience, management failure to work with subordinates, different understanding of the company's operation goal, objectives and their implementation.

2. Personnel risks - the risks related to a company's employees involved in the work, such as lack of knowledge or skills, staff turnover, lack of human resources at the organisation or their ineffective allocation to carry out activities, sudden illness of the employee, irresponsibility of the employee, negligence, resignation of a skilled employee, changes in an employee's character, behaviour, health condition, skills of employees - inadequate experience, knowledge. To reduce the likelihood of this risk, the company employs skilled employees with professional knowledge and a high level of responsibility.

3. Financial risks - the risks associated with financial instruments, such as a lack of financing, lack of market price awareness, improperly planned financial flows and inflation, due to which planned costs can significantly differ from real costs (Zhai \& Bai, 2018). The financial risk is related to the possibility of a company suffering financial losses (Ma \& Meng, 2009): penalties, unpaid tenant's services (unfair customer behaviour), mistakes in the budget plan, insolvency of clients, increase in the VAT rate for public services, increase in the excise tax on heat supply services, and inflation. The activities of the company include various measures that would improve customer payment discipline, such as regular work with debtors, or drawing up payment schedules for customers to enable them to make part payments prior to the heating season.

4. Implementation risks - the risks that occur when processes or procedures are malfunctioning or not functioning at all, resulting in significant impediments or delays in the work, such as inaccurate/illogical work planning, incomplete/inadequate organisational structure, inaccurately/unclearly defined tasks, insufficient information security etc.

5. Legal risks - the risks related to non-compliance with the requirements of the current regulatory enactments (Ma \& Meng, 2009), non-compliance with contractual obligations and other legal aspects, including incorrect procurement procedure.

6. Production risks - an important risk at the company as this risk is related to the probability that the company cannot fulfill its obligations to the client due to various unforeseen circumstances (for example, interruption of heat supply to 
residential buildings, electrical power interference etc.). One of the reasons of the risk can be equipment damage, deterioration or aging.

7. Commercial risks - innovations, changes in the service market, new requirements in service standards that the company is not able to meet. In order to reduce the probability of occurrence of commercial risks, the company performs a market analysis by analysing information about the industry, costs, advantages and drawbacks. The obtained information is taken into account when preparing the range of provided services and the price list with the aim of providing the highest quality services at lower prices. In order to provide modern services, the company keeps track of industry innovations.

8. Political risks - changes in national policies affecting the industry, the risk of loss arising from events occurring in the country or region that adversely affect the political situation in the country, the stability of the political system.

9. Technical risks - poor condition of old buildings, high wear and tear, obsolete technologies, non-provision of maintenance, non-compliance with technical standards/instructions.

The assesment of the risks of the study provide quantitative basis for optimal decision-making process at the planning stage of enterprise operation (Bezrukovs \& Sauhats, 2017).

Entrepreneurship will always be a subject to risk, because the risk is always existent, whether you are aware of it or not.

On the basis of enterprise's operations, the risk assessment procedure scheme is created, whose analysis is a component of the risk assessment process (Ziemele \& Voronova, 2012).

A business strategy usually requires that problems are identified, potential risks are assessed, and appropriate control measures taken to address the risk. Risk assessment is a thorough reaserch of what constitutes a hazard to humans or the environment in the course of a project, taking into account the probability of occurrence of the hazard and the severity of the consequences, thus allowing one to assess the risk (Nord Stream, 2002).

The risk assessment can be qualitative and quantitative:

a. Qualitative (e.g., probability and consequences are calculated using the scale from "very low" to "very high");

b. Quantitative (e.g., the probability is estimated by examining the frequency of cases per year and evaluating the consequences by the number of victims).

To determine the risk priority, it is necessary to use the point method, paying attention to the frequency of the risks, the level of the risk impact on the project funding, and implementation period (Ziemele \& Voronova, 2012).

Treatment of risk in the management literature largely focuses on particular uncertainties to the exclusion of other interrelated uncertainties. It is necessary to develop a framework for categorising the uncertainties faced (Miller, 1992) by firms operating in the real estate field and outline economic, technical, social, financial and strategic risk management responses (Kočanova, Geipele, Niedrīte, 2013).

Risk assessment is a predictive technique that typically uses historical data, modelling, assumptions and expert judgments, and therefore there is always a 
degree of uncertainty in the risk assessment. In the absence of relevant information, risk assessment and risk management decisions are usually appropriately cautious, providing a higher level of protection as the risk is increased and the level of uncertainty is increased (Nord Stream, 2002).

\section{CASE STUDY AT A MUNICIPAL ENTERPRISE: RENT HOUSING MANAGEMENT AND RISK IN THE MUNICIPAL PROPERTY}

To promote the development of housing stock, ensure the construction and renovation of dwellings and other real estate objects in Riga, as well as to optimise the performance of functions of Riga city municipality, based on the laws of the Republic of Latvia "On Local Governments", "On Local Government Assistance in Solving Apartment Matters", Riga City Council has established its own company, which ensures new housing development, construction and management.

During the period of 2002-2011, the company replenished the housing stock of Riga city municipality with 4510 well-equipped apartments. Moreover, the residential building complex Dreilini, which was started and terminated in the Soviet times, was completed. Upon completion of the terminated buildings and construction of newly built residential buildings, 14 multi-storey multi-apartment residential buildings have been constructed (Rīgas pilsētbūvnieks, n. d.).

In the period from 1 January 2009 to 31 December 2014, 2689 apartments with a total living space of $120787 \mathrm{~m}^{2}$ were commissioned for the development of Riga municipality housing stock. The largest residential area consists of a building complex at 13 Ulbrokas Street in Riga, with a total of 5 buildings with a total area of $40408 \mathrm{~m}^{2}$. The next largest area of living space is the property at 58 Valdeku Street in Riga purchased through public procurement, with a total living area of $11132 \mathrm{~m}^{2}$. The third largest facility is located at 22, 26, 28 and 30 Mežrozī̌su Street with a total living area of $10932 \mathrm{~m}^{2}$ (Rīgas pilsētbūvnieks, n. d.).

The overall strategic goal of company $X$ is the development and renewal of municipal housing stock, the design, reconstruction and building of public facilities, rational and efficient management and administration of municipal real estate, including social housing, improvement of the administrative territory and maintenance of sanitary purity (construction, reconstruction and lighting of streets, squares and other public areas; installation and maintenance of parks, squares and green spaces).

As of 1 January 2017, there are 63 residential buildings under the management and administration of the company (including social residential buildings -17 ) (Rīgas pilsētbūvnieks, n. d.).

To more effectively achieve the set strategic goals, at the end of 2012, the company started to improve its internal control system and introduced the quality management system ISO 9001 with the aim to increase the company's operation efficiency, optimise the organisation management model, as well as identify and reduce the risks associated with the company's operations.

The problems or potential risks of a company operating in the real estate management sector of Riga are attributed to the following factors: 
1) the financial and economic situation in the country, especially taking into account changes in electricity tariffs in the direction of growth, employment rate, income level, household consumption level for management services and utilities. Consequently, in this situation, the purchasing power risk of the population increases, which means that the company may have to reduce or change the range of services provided, change the emphasis related to the prices of paid services. If the gray economy is growing, the risk increases that citizens become involved in criminal activities; as a result, the system of people's values changes, and the morale of the people decreases;

2) fluctuations in heating costs depending on outdoor air temperature during the heating season;

3) the outdoor air temperature and the amount of precipitation, their persistence in winter, which imply the amount of expenses incurred in the maintenance of administered areas and roof cleaning;

4) the amount of funds allocated to social assistance by Riga and other municipalities depending on the location of the residential buildings managed and administered by company;

5) the amount of the rent, which should include the amount of funds necessary for the maintenance of the building and, accordingly, observance of the tenants' payment discipline, paying for the invoices drawn up;

6) one of the most important problems is the attitude of certain social groups and individuals towards the property belonging to the municipality. It is often not possible to punish such individuals administratively, as there are no relevant laws and regulations.

Risk can be assessed through a measure of impact or consequence. An assessment scale for assessing the impact of risks can be made (see Table 1). For example, in Table 1 the authors have reflected some of the most important and topical risks, as well as the possible actions for their mitigation.

As can be seen from the risks identified in Table 1, an important risk, the occurrence of which is often or almost always forecasted first of all, is the financial and economic situation in the country. Consequently, the authors will further examine the factors influencing the management of municipal residential buildings.

Table 1. Risk Assessment Matrix (table made by the authors)

\begin{tabular}{|l|l|l|l|}
\hline Risks & $\begin{array}{l}\text { Likelihood of } \\
\text { occurrence }\end{array}$ & $\begin{array}{l}\text { Impact on } \\
\text { performance } \\
\text { results }\end{array}$ & Risk reduction measures \\
\hline $\begin{array}{l}\text { Financial and } \\
\text { economic situation in } \\
\text { the country }\end{array}$ & Almost always & Crucial & $\begin{array}{l}\text { To continuously keep track of } \\
\text { economic changes in the } \\
\text { country, help tenants find jobs, } \\
\text { where possible, provide } \\
\text { information on the possibilities } \\
\text { to receive benefits }\end{array}$ \\
\hline $\begin{array}{l}\text { Increase in the } \\
\text { company's expenses }\end{array}$ & Seldom & $\begin{array}{l}\text { Crucial rather } \\
\text { than insignificant }\end{array}$ & $\begin{array}{l}\text { To increase the number of } \\
\text { employees within the company } \\
\text { by reducing the outsourcing } \\
\text { practice }\end{array}$ \\
\hline
\end{tabular}




\begin{tabular}{|l|l|l|l|}
\hline Risks & $\begin{array}{l}\text { Likelihood of } \\
\text { occurrence }\end{array}$ & $\begin{array}{l}\text { Impact on } \\
\text { performance } \\
\text { results }\end{array}$ & Risk reduction measures \\
\hline $\begin{array}{l}\text { Amount of rent, } \\
\text { tenants' solvency }\end{array}$ & Almost always & Crucial & $\begin{array}{l}\text { Economic justification for the } \\
\text { increase in rent, work with } \\
\text { debtors, involvement of social } \\
\text { service }\end{array}$ \\
\hline $\begin{array}{l}\text { Tenants' attitude } \\
\text { towards the property } \\
\text { owned by the } \\
\text { municipality }\end{array}$ & Almost always & $\begin{array}{l}\text { Insignificant } \\
\text { rather than crucial }\end{array}$ & $\begin{array}{l}\text { In the rental contracts, there } \\
\text { should be a greater } \\
\text { responsibility (administrative, } \\
\text { civil, criminal) imposed on } \\
\text { tenants for damaging property; } \\
\text { in the event of damage to } \\
\text { property, to initiate } \\
\text { proceedings against a tenant }\end{array}$ \\
\hline $\begin{array}{l}\text { Non-compliance with } \\
\text { technical } \\
\text { standards/instructions }\end{array}$ & Unlikely & $\begin{array}{l}\text { To determine the level of } \\
\text { responsibility in employment } \\
\text { contracts, job descriptions. } \\
\text { Recruitment of professional } \\
\text { employees }\end{array}$ \\
\hline $\begin{array}{l}\text { Processes or } \\
\text { procedures are } \\
\text { malfunctioning or not } \\
\text { functioning at all }\end{array}$ & Unlikely & $\begin{array}{l}\text { Implementation and } \\
\text { maintenance of the quality } \\
\text { management system in the } \\
\text { company }\end{array}$ \\
\hline
\end{tabular}

The main aim of the effective management processes is low costs, high-quality services and solvent homeowners, tenants, renters or users.

Examining indicators of the economic activity in the state, according to the Central Statistical Bureau, the unemployment rate is gradually decreasing in the period from 2012 to the end of 2016 (see Fig. 1). The highest unemployment rate was in 2012 due to the ongoing economic crisis in the country, while by the end of 2016 the unemployment rate decreased by $5.4 \%$. Such positive macroeconomic changes affect management processes because along with the improvement of the economic situation the consumer solvency is increasing (Central Statistical Bureau, n. d.).

The high proportion of jobseekers, especially by 2012, demonstrates the problems in the labour market and the problem situation of the population in the field of employment. Such negative features have a severe impact on management processes since, along with negative trends in employment, management processes are also suffering because long-term job seekers have problems related to paying for management services (Central Statistical Bureau, n. d.). 


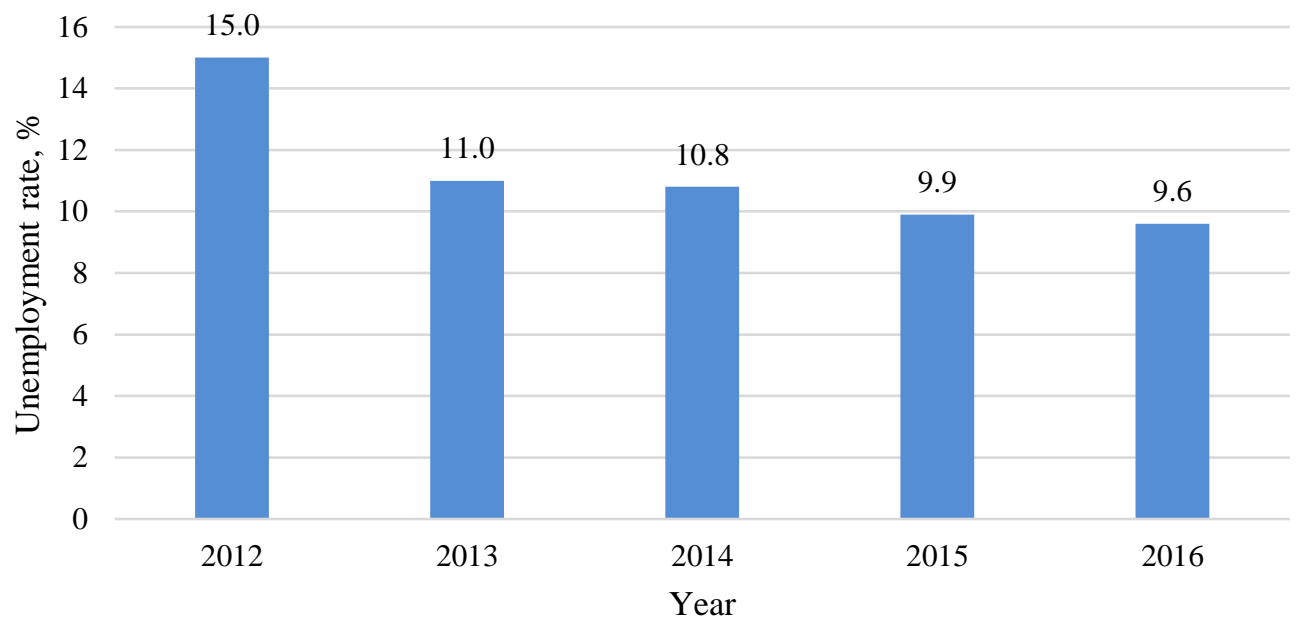

Fig. 1. Unemployment rate for the period of 2012-2016 in Latvia (Central Statistical Bureau, n. d.).

As the economic situation in the country improves, there are also positive trends observed in the labour market - unemployment is decreasing and the employment rate is increasing; the average monthly gross wage was EUR 865.50 in 2016, according to the data of the Central Statistical Bureau (see Fig. 2). Compared to the previous year, it increased by $4.65 \%$. In the private sector, the average monthly gross wage was EUR 799, in the public sector - EUR 855 . In the private sector, salaries increased by $5.8 \%$ per year, while in the public sector - by $3.7 \%$ (Central Statistical Bureau, n. d.).

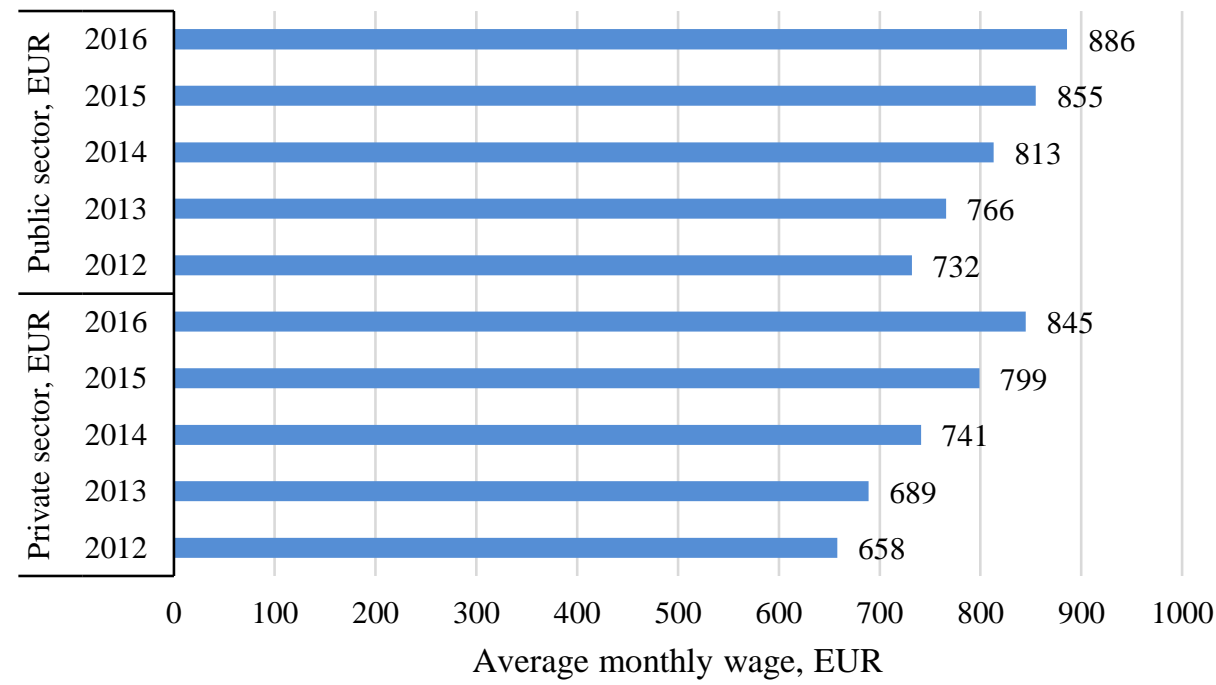

Fig. 2. Average monthly wage (gross, EUR) for the period of 2012-2016 in Latvia (Central Statistical Bureau, n. d.). 
From 1 January 2017, the country's minimum wage is EUR 380. It is a small increase of $2.63 \%$; however, this may have an impact on the expenses of companies administering residential buildings, as a large part of workers, such as janitors and cleaners, receive the minimum wage set by the country. With the increase of the minimum wage, it is expected that the management fee may increase.

Households that have the lowest income need to devote most of the income to basic needs - food and housing. Almost every second household that has children ranked in the first quintile group (the poorest) by the income level per household member in 2014, while the fifth quintile group (the wealthiest) comprised three times smaller proportion of households with children (see Fig. 3) (Central Statistical Bureau, n. d.).

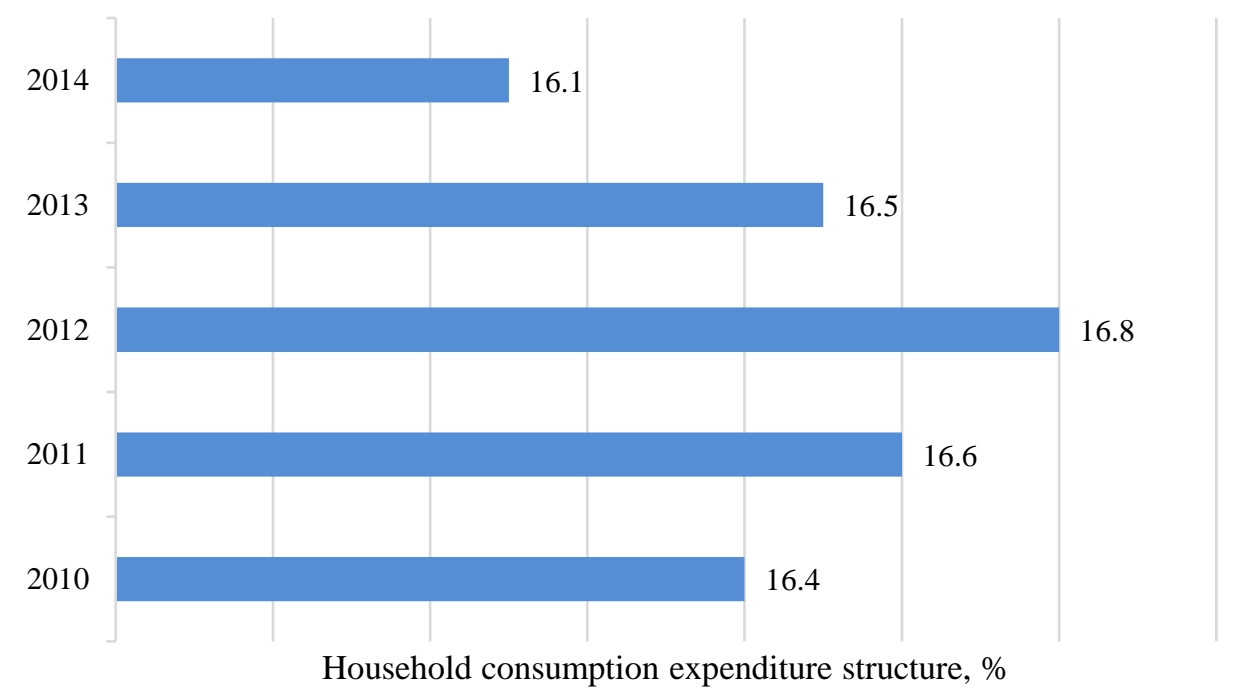

Fig. 3. The structure of household consumption expenditure (\%) for the period of 2010-2014 in Latvia (Central Statistical Bureau, n. d.).

One of the key factors influencing the entire management process is the management expenses of residential buildings and factors influencing price formation.

The rent is made up of two parts: the profit, which, in the case of the municipality as the owner, is approved by the council decree, and the management fee. The latter depends on the technical condition of the building and the need of renovation works.

In the city of Riga and its region, the management fee has risen from 45 cents per month per square meter to 57.5 cents per month per square meter over a fiveyear period (see Fig. 4). 


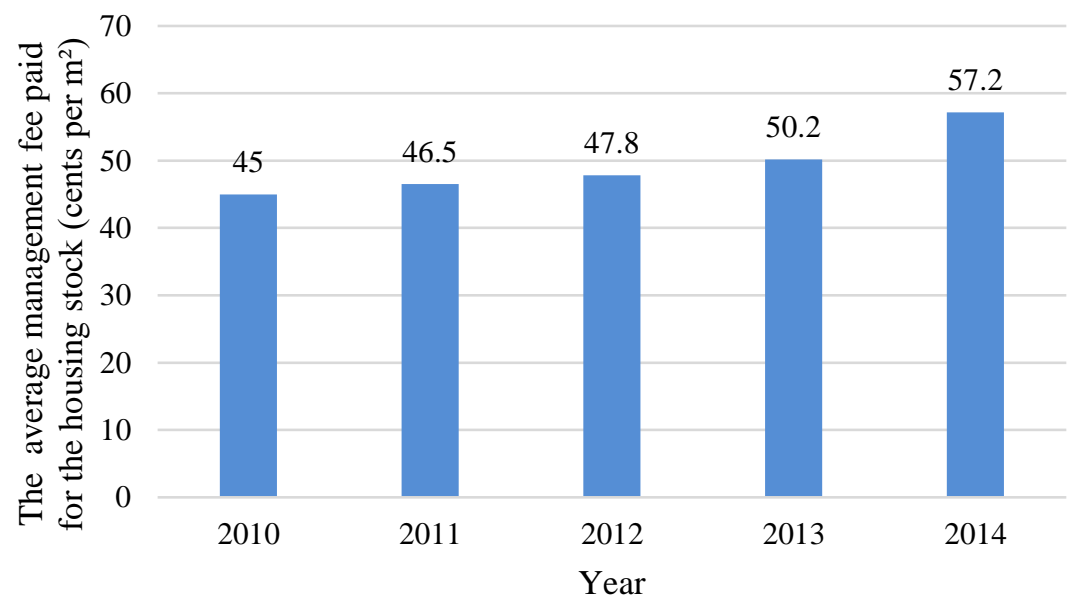

Fig. 4. The average management fee paid for the housing stock in the city of Riga and its region (cents per $\mathrm{m}^{2}$ ) (Central Statistical Bureau, n. d.).

However, as of 1 July 2016, amendments to the law came into force, as the government approved the budget for the subsequent year, and in 2016 managers of the building had to issue larger invoices to tenants of multi-apartment buildings. Building management services will be subject to $21 \%$ VAT, which has not been applied to date.

An essential risk - tenants' attitude towards municipal property. The authors of the research have conducted an expert interview to find out how this risk affects the rental property maintenance process. During the interview, it has been found that in almost every rental building there are people who have got their living space by acquiring a social apartment status. Tenants' attitude towards municipal property is regarded as a low level of responsibility. As a result of the tenants' actions, the buildings are subject to technical damage, hygiene conditions are not met, as well as payments are not made on time. All these activities and inactivity conditions contribute to the deterioration of the technical condition of rental buildings, and also lead to the increase in their maintenance fees because after damage identified in the building, additional funds should be invested in order to remedy the defects.

Therefore, in order to ensure successful management of risks in the management of residential buildings, it is necessary to insure both one's own business and all the property.

Insurance is an integral part of the financial market. The principal financial riskreduction techniques are purchasing the insurance (Miller, 1992).

Nowadays insurance companies cover expenses related to many kinds of movable and immovable property entrusted to another person and their property. An insurance premium will be higher for an item that is in poor technical condition. This means that if one of the managed buildings is in bad condition, then insurance of the building will have a more expensive insurance premium. Before buying the insurance policy, you need to understand what risks a particular management company needs to insure and what the insurance rules are.

The insurance role is very important in the field of management. Its purpose is to accumulate funds in advance in order to compensate losses when they arise. In 
theory, when losses have incurred is too late, but it must be understood that no manager can act completely excluding risks; there are many factors that influence management. Therefore, when an enterprise concludes an insurance contract, it is possible to insure exactly those risks that the entrepreneur considers necessary for their business.

One of the major problems in Riga municipality is the provision of households with living space. Economic factors have a significant impact on the accessibility of housing. To provide residents of Riga with an opportunity to live in a dwelling, several registers have been created in Riga municipality, depending on which rental apartments are also granted.

One of the risk factors in the management of municipal apartments is the persons entitled to receive apartments for rent.

Since 2010, the queue for municipal apartments in Riga has become almost twice smaller. On 1 June 2016, 4,026 families waited in the queue - those entitled to receive residential space from the municipality. Riga City Council has expanded the range of people who can receive assistance in resolving the housing issue. Now they are also:

1) families with three or more children;

2) persons who have lost their only dwelling because they have not been able to pay off mortgage;

3) persons who live in municipal buildings (in former dormitories), which are in the unsatisfactory technical condition.

In accordance with Regulation No. 153 "On Registration and Assistance in Resolving Housing Issues" as of 9 June 2015, the income threshold for tenants of denationalised buildings has increased by EUR 40 per month, which allows registering for assistance in resolving housing issues. When constructing social buildings, serviced apartments are created for people who use a wheelchair.

Under the new regulations, all these persons are listed in ten registers.

1. Persons who have the right to social living space. They are low-income pensioners living alone and persons with disabilities of group 1 or 2 , families with children with disabilities, if the child is not provided with a separate room, as well as people who need a serviced apartment because they are forced to use a wheelchair.

2. Persons who have been expelled from an apartment due to rent and utility debts or because they have not been able to pay off mortgage taken for the purchase or repair of the only dwelling.

3. Children who are left without parental care as well as orphans.

4. Tenants of denationalised buildings who qualify for a single living allowance for vacating an apartment on condition that their income does not exceed a certain level - the income of a single person living alone does not exceed EUR 440, but in a family consisting of two or more people, the income per person does not exceed EUR 360 a month after tax.

5. Persons released from detention centers.

6. Families with three or more minor children.

7. Tenants of denationalised buildings whose income for a single person living alone does not exceed EUR 440, but for the family - EUR 360 per person a month. 
8. Persons living in municipal living spaces that are declared to have improper living conditions, as well as residents of denationalised buildings that are in the same condition. They are offered to rent living space with a number of rooms that are equivalent to the previously rented living space.

9. Register is an "exchange register". It includes people who live in municipal apartments and have expressed their desire to move to a smaller or cheaper dwelling, including apartments with partial comfort.

10.Persons applying for municipal assistance according to a general procedure (since 2009 admission to this register has been discontinued) (Riga City Council, 2017).

Information from the registers suggests that most of the company's customers are people living on low incomes, with some burden (mortgage) or significant health problems. Only the 10th register refers to persons who receive rental rights according to a general procedure. Consequently, it can be concluded that municipal apartments are identified as a form of social assistance, which in turn increases the risk of an increase in receivables for the services received (Riga City Council, 2017).

The major risk is considered to be the tenants' solvency, which is related to the income of a person, the employment rate, the attitude of tenants and their family members to the municipal property, as well as the level of consciousness and responsibility for the use of the property and received services.

Consequently, in financial management, the most important task is the monitoring and management of receivables with an aim of optimising the number of receivables and collecting them in a timely manner (Rurāne, 2006, 60).

Receivables are assets that arise from the right of a company to receive economic benefits from legal or natural entities. If there is a high probability that receivables are to be paid unless the contrary is proven, there is a sufficient reason to recognise debts as a company's assets (Ludboržs, 2007, 134).

To ensure the quality of property management, at the risk identification and analysis stage it is necessary to develop an action plan. The purpose of an action plan is to document policies and procedures for identifying and handling causes of enterprise's operation (i.e., risk). Risk should be thought of as the possibility of suffering a negative impact by the enterprises, whether it is decreased quality, increased cost, delayed completion, or operation failure.

\section{CONCLUSION}

In order to successfully accomplish the tasks, the manager should be aware of the role of these tasks in the overall operation of the building. The main goal of efficient process management is low costs, high-quality services and solvent homeowners, tenants, renters or users. The manager, who also performs the function of "social networking" among residents, including tenants, can significantly improve the efficiency of the management process in terms of psychological readiness and feedback.

Management fee is the value of the service in monetary terms, the consumer's fee for the benefit of the use of the service. Given the tendency of recent years as 
well as the current increase in the minimum wage, the management fee is expected to increase with each passing year.

Revenues from rental of social housing are too small and insufficient to at least partly finance energy efficiency and improvement measures, and municipalities have insufficient funds that could be envisaged in the budget for taking the abovementioned measures in social housing.

A company should be informed about its customers' solvency, their outstanding liabilities, and perform effective accounting and administration of its receivables.

The risk is the end result of probabilities, dangers, causes and consequences (which can be summarised for all potential accident scenarios that are related to the system, operation, or process).

Insurance is a fight against consequences. Risk management should be used to deal with risks, thus initially trying to find out the causes of the problems in order to avoid or reduce these problems in the future.

Determining and collecting the expenses necessary for rental housing management are the main manager's tasks, which should be implemented in order to successfully and continuously carry out the management functions by administering residential houses. The main task of the manager in collecting payments from tenants for the services received is to establish effective communication with them and persuade the owners to pay all bills in full and on time.

A municipal company that provides rental housing management should choose its own strategy and organisational structure for risk management based on the industry specifics, customers, weaknesses and strengths of the institution and many other factors, but it is important in its choice to achieve a balance between resources invested in risk management activities and the benefits of this instrument.

\section{REFERENCES}

Bezrukovs, D., \& Sauhats, A. (2017). Economic and Operational Risks in Wind Energy Projects in Latvia. Renewable Energy and Power Quality Journal, 1(15), 377-382. ISSN 2172-038X. https://doi.org/10.24084/repqi15.326

Carkovs, J., \& Šadurskis, K. (2015). Markov Switched Difference Equations of Investment Risk Analysis. In Proceedings of the 14th Conference on Applied Mathematics APLIMAT 2015 (pp. 175-190). Bratislava: Slovak University of Technology in Bratislava, Publishing House of STU. ISBN 978-80-227-4143-3

Central Statistical Bureau. (n. d.). Retrieved November 30, 2017, from http://data.csb.gov.lv/

Ghoshal, S. (1987). Global Strategy: An Organizing Framework. Strategic Management Journal, 8(5), 425-440. https://doi.org/10.1002/smj.425008050

Ludboržs, A. (2007). Apgrozāmā kapitāla vadī̌ana nelielos uzn̄èmumos [Working Capital Management in Small Businesses]. Latvia, Riga: LID Publishing House. 288 p. ISBN 998-497895-8 (in Latvian).

Kočanova, R., Geipele, I., \& Niedrīte, V. (2013). Stratēgiskās vadī̌̌anas sistēma organizāciju ilgtspējīgai attīstībai [Strategic Management System for Sustainable Development of Organizations]. Latvia, Riga: RTU Press. 175 p. ISBN 978-99-341-0348-3 (in Latvian).

Ma, Z., \& Meng, O. (2009). The Research on Risk Evaluation of Real Estate Development Project Based on RBF Neural Network. Second International Conference on Information and Computing Science, 2, 273-276. https://doi.org/10.1109/icic.2009.180

Meiers-Meiris, I., Mazais, J., \& Lapiṇa, I. (2017). Risk Management Framework for Integrated Management Systems. In Proceedings of 20th QMOD-ICQSS Conference "Challenges and 
Opportunities of Quality and Sustainability in the 4th Industrial Revolution" (pp. 1-17). Denmark, Elsinore, 5-7 August 2017. Lund: Lund University Library Press. ISBN 978-91-762-3086-2

Miller, K. D. (1992). A Framework for Integrated Risk Management in International Business. Journal of International Business Studies, 23(2), 311-331. https://doi.org/10.1057/palgrave.jibs.8490270

Nord Stream. (2002). The New Gas Supply Route for Europe. Retrieved November 29, 2017, from http://media.nord-stream.com/media/news/facts/en/2008/09/the-new-gas-supply-route-toeurope_20080901.pdf

Pukīitis, A., Pukīite, I., \& Geipele, I. (2017). Rental and Management Policy of Municipal Residential Buildings: Housing Policy. Case Study of Riga (Part One). Baltic Journal of Real Estate Economics and Construction Management, 5, 287-301. e-ISSN 2255-9671. https://doi.org/10.1515/bjreecm-2017-0022

Riga City Council. (2017). Kã sanemt mājokli no pašvaldības?. Retrieved November 29, 2017, from https://www.riga.lv/lv/news/ka-sanemt-majokli-no-pasvaldibas?9052

Rīgas pilsētbūvnieks. (n. d.). Par mums [About us]. Retrieved November 29, 2017, from http://www.rigaspilsetbuvnieks.lv/lv/par-mums/par-mums

Rurāne, M. (2006). Finanšu menedžments [Financial Management]. Latvia, Riga: "RISEBA" University of Business, Arts and Technology Publishing House. 383 p. ISBN 998-47-0512-9 (in Latvian).

State Education development Agency Republic of Latvia. (2017). Vadlinijas projekta risku pārvaldībai. [Guidelines for Project Risk Management]. Retrieved November 30, 2017, from sf.viaa.gov.lv/library/files/original/12242_vadlinijas_riski.doc

Zhai, J., \& Bai, M. (2018). Risk Model for Uncertain Portfolio Selection With Background Risk. Journal of Computational and Applied Mathematics, 330, 59-69. https://doi.org/10.1016/j.cam.2017.07.038

Ziemele, J., \& Voronova, I. (2012). Provision of Insurance Companies' Financial Stability in Project Management. Economic Research in Business, 10, 161-172. ISSN 1691-0737.

\section{AUTHORS' SHORT BIOGRAPHIES}

Iveta Pukīte, Mg. sc. ing., a Researcher at the Faculty of Engineering Economics and Management of Riga Technical University (RTU) and a Doctoral student at RTU. She received the Master's degree in Management Sciences from the University of Latvia. She is a Lecturer at the College of Law and the Head of Real Estate Management Department at Ādažu Namsaimnieks Ltd. I. Pukīte has participated in the international scientific conference "Economic Science for Rural development", Jelgava, Latvia, in the 3rd European interdisciplinary forum "Drivers for Progress in the Global Society", Vilnius, Lithuania, and others. Her research area is the socially responsible housing lifecycle of the management system.

ORCID iD: http://orcid.org/0000-0003-2500-0501

Ineta Geipele is a Professor of the Faculty of Engineering Economics and Management, Director of the Institute of Civil Engineering and Real Estate Economics, the Head of the Department of Civil Construction and Real Estate Economics and Management at Riga Technical University, Latvia. She improved her professional skills in Austria, Germany, Denmark and the UK. Ineta Geipele is the author and co-author of more than 300 scientific publications. Her current research areas are sustainability development problems of real estate market, construction industry, land use management and institutional economics. Professor Ineta Geipele is an expert of the Latvian Academy of Sciences in Management and Economics at the Latvian Council of Science, a board member of the FIABCI-Baltic Multinational Chapter and of the Cunfte of the Facility Management of Latvian Housing, and a member of the Latvian Union of Civil Engineers.

ORCID iD: http://orcid.org/0000-0002-2963-087X

Armands Pukīitis, Bc. sc. ing., studied at the Faculty of Engineering Economics and Management of Riga Technical University (RTU) and received Bachelor's degree in Real Estate Management. He has 10 years of experience in the real estate field and he is a manager of real estate at Rigas Pilsētbūvnieks Ltd. His research area is municipal residential building. 